\title{
Investigation of the Rheological Properties of Ointment Bases as a Justification of the Ointment Composition for Herpes Treatment
}

\author{
Herpes Tedavisi İçin Merhem Bileşiminin Doğrulanması Amacıyla Merhem \\ Bazlarının Reolojik Özelliklerinin Araştırılması
}

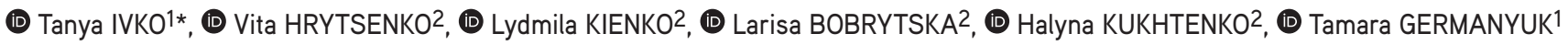 \\ ${ }^{1}$ National Pirogov Memorial Medical University, Department of Pharmacy, Vinnytsya, Ukraine \\ 2National University of Pharmacy, Department of Industrial Technology of Drugs, Kharkiv, Ukraine
}

\begin{abstract}
Objectives: Combinatorial drugs are among the leading pharmacotherapeutic agents, including those used for the treatment of herpetic infections, which require complex treatment. We have developed a soft dosage form of ointment, which includes acyclovir and miramistin, which have antimicrobial, anti-inflammatory, and local immunoadjuvant activity. The study aimed to investigate the rheological properties of ointment bases in order to substantiate the composition of a soft dosage form with antiviral effect using the active ingredients miramistin and acyclovir.

Materials and Methods: The object of the study was to determine the heterogeneous and homogeneous composition models of the bases made using a wide range of excipients. Structural and mechanical studies were performed using the "Rheolab QC" rotary viscometer by Anton Paar (Austria) with coaxial cylinders CC27/S-SN29766. The rheological parameters were investigated at a temperature of $25^{\circ} \mathrm{C} \pm 0.5^{\circ} \mathrm{C}$. The samples were thermostated using a thermostat MLM U15c. The batch of sample weighing about $15.0 \pm 0.5 \mathrm{~g}$ was placed in the container of an external stationary cylinder. The required temperature of the experiment was set and the thermostating time was 20 min. The device is equipped with RheoPlus 32 V3.62 software.

Results: The rheological behavior of the model compositions was analyzed in terms of indicators, such as yield strength, hysteresis square, coefficients of dynamic flow, and mechanical stability. It was found that all samples have a non-Newtonian pseudoplastic type of flow. The model of spreading optimums was used to evaluate consumer properties. According to the rheological parameters, it is advisable to use the sample based on paraffin and vaseline oil for further research.

Conclusion: The findings from this study will be relevant in the development of the soft dosage form for the treatment of herpes viral diseases.

Key words: Ointment bases, soft dosage forms, rheology, structural and mechanical properties
\end{abstract}

Öz

Amaç: Kombinatoryal (birleșimsel) ilaçlar, karmașık tedavi gerektiren herpetik enfeksiyonların tedavisinde kullanılanlar da dahil olmak üzere önde gelen farmakoterapötik ajanlar arasındadır. Antimikrobiyal, anti-inflamatuvar ve lokal immünoadjuvan aktiviteye sahip asiklovir ve miramistin içeren merhemin yumuşak bir dozaj formunu geliştirdik. Çalışma, miramistin ve asiklovir aktif bileşenleri kullanılarak antiviral etkiye sahip yumuşak bir dozaj formunun bileșimini doğrulamak için merhem bazlarının reolojik özelliklerini araștırmayı amaçladı.

Gereç ve Yöntemler: Çalışmanın amacı, çok çeşitli yardımcı maddeler kullanılarak yapılan merhem bazlarının heterojen ve homojen bileşim modellerini belirlemektir. Yapısal ve mekanik çalışmalar, koaksiyel silindirler CC27/S-SN29766 ile Anton Paar (Avusturya) tarafından üretilen "Rheolab QC" döner viskozimetre kullanılarak gerçekleştirilmiştir. Reolojik parametreler $25^{\circ} \mathrm{C} \pm 0,5^{\circ} \mathrm{C}$ sıcaklıkta belirlenmiştir. Numunelerde, bir termostat $\mathrm{MLM}$ U15c kullanılarak sıcaklık kontrolü sağlandı. Yaklaşık 15,0 0,5 g ağırlığındaki numune yığını, harici bir sabit silindirin kabına yerleştirildi. Deney için gerekli sıcaklık ayarlandı ve termostatlama süresi 20 dakikaydı. Cihaz RheoPlus 32 V3.62 yazılımı ile donatılmıştır.

Bulgular: Model kompozisyonlarının reolojik davranışı, akma dayanımı, histerezis karesi, dinamik akış katsayıları ve mekanik kararlıık gibi göstergeler açısından analiz edildi. Tüm örneklerin Newtonyen olmayan bir psödoplastik akış tipine sahip olduğu bulundu. Tüketici özelliklerini değerlendirmek 
için yayılma optimumları modeli kullanıldı. Reolojik parametrelere göre, daha fazla araştırma için parafin ve vazelin bazlı numunenin kullanılması tavsiye edilir.

Sonuç: Bu çalıșmanın bulguları, herpes viral hastalıklarının tedavisi için yumuşak dozaj formunun geliștirilmesinde yararlı olacaktır.

Anahtar kelimeler: Merhem bazları, yumuşak dozaj formları, reoloji, yapısal ve mekanik özellikler

\section{INTRODUCTION}

Soft dosage forms are dispersed systems with a viscousplastic dispersed medium characterized by a non-Newtonian type of flow. Their viscosity at a given temperature and shear stress varies non-linearly, depending on the shear rate. ${ }^{2,3}$

When developing the composition of soft dosage drugs, much attention is paid to the study of their rheological properties and the structural and mechanical parameters determine the stability of viscose-dispersed systems. ${ }^{4}$ A comprehensive study of rheological characteristics is of both theoretical and practical interest, since they can be an effective and objective criterion for quality control at the stage of creation, production, storage, and use of drugs., 5 The rheological properties affect the release of medicinal substances, therapeutic efficacy of drugs, consumer requirements (the process of extrusion from tubes, convenience, and ease of lubrication on the skin), and production characteristics (the process of dispersion and packaging) ${ }^{7-9}$

Soft dosage forms are complex systems that contain a base and active ingredients. ${ }^{10}$ Properly selected base provides the necessary speed and completeness of the medicinal substances released, comfort in usage, and stability during storage of drugs.11,12 Therefore, the study of the structural and mechanical properties of ointment bases is an important step in the development of soft dosage forms. ${ }^{13-15}$

Today, combinatorial drugs are among the leading pharmacotherapeutic agents, including those used for the treatment of herpetic infections, which require complex treatment. Choice of drug combination allows the expansion of drug action and the complex influence on diseases, enhances the activity of every ingredient, improves tolerability, and reduces side effects. ${ }^{16-19}$

Herpetic infections occur in the form of mono-, mixed and coinfections and can be asymptomatic (latent), in an acute, chronic persistent form with a recurrent course, as well as in the form of an atypical chronic active infection. ${ }^{20}$ Currently, the combined drugs are leading among pharmacotherapeutic agents, including the treatment of herpetic infections, which require complex treatment. Drug combination choice allows to expand the range of action of the drug and the complex influence on the disease, activity of the every ingredient, as well to improve tolerability. ${ }^{21-26}$ We have developed a soft dosage form in the form of an ointment, which includes acyclovir [TEVA Pharmaceutical and Chemical (Hang-zhou) Co., Ltd, China] and miramistin (Infamed LLC, Russia), which has antimicrobial, anti-inflammatory and local immunoadjuvant action.

\section{MATERIALS AND METHODS}

The objects of the study were ointment bases (Table 1). The ointment bases, which have been developed using excipients that are widely used in soft dosage technology, were obtained were obtained at National University of Pharmacy, Department of Industrial Technology of Drugs. The excipients used includes propylene glycol (BASF SE, Germany), ${ }^{27}$ proxanol-268 (NPF "Perftoran" OJSC, Russia), polyethylene oxide-400 (Dow Chemical, Germany), ${ }^{28}$ vaseline oil(Borma wachs, Italy), ${ }^{27}$ paraffin (LLC “Novokhim," Ukraine), cetostearyl alcohol (Guangzhou Yiming Chemical Material Co., Ltd., China), ${ }^{29}$ twin-80 (MN \& Gustav Heess Ukraine, Ukraine), carbopol 934 (Kylin Chemicals Co., Ltd., China), triethanolamine (LLC “Novokhim”, Ukraine),27 corn oil (Nordolio, Italy), eucerit (LLC NPP “Electrogazokhim" Ukraine), aristoflex AVC (Clariant, Switzerland), vaseline (Balea, Germany), ${ }^{27}$ emulsifier "Solid-2" (LLC NPP “Electrogazokhim", Ukraine), isopropylmyristate ${ }^{30}$ (MN \& Gustav Heess Ukraine, Ukraine), ${ }^{23}$ and hydroxyethylcellulose (LLC "Linkchem", Ukraine). The rheological (structural-mechanical) properties of the bases were determined using a "Rheolab QC" rotary viscometer (Anton Paar, Austria) with coaxial cylinders CC27/ S-SN29766. The rheological parameters were investigated at a temperature of $25^{\circ} \mathrm{C} \pm 0.5^{\circ} \mathrm{C}$. The samples were thermostated using a thermostat MLM U15c.

The batch of sample weighing about $15.0 \pm 0.5 \mathrm{~g}$ was placed in the container of an external stationary cylinder; the required temperature of the experiment was set and the time of thermostating was $20 \mathrm{~min}$. The device is equipped with RheoPlus 32 V3.62 software. Measurements of the rheological flow curve were performed in 3 stages:

1. Linear increase at the rate of shear velocity from $0.1 \mathrm{~s}^{-1}$ to $350 \mathrm{~s}^{-1}$ with 105 measurement points and duration of the measurement point is $1 \mathrm{~s}$;

2. Constant shift at a speed of $350 \mathrm{~s}^{-1}$ for $1 \mathrm{~s}$ of duration;

3. Linear decrease at the rate of shear velocity from $350 \mathrm{~s}^{-1}$ to $0.1 \mathrm{~s}^{-1}$ with 105 measurement points and duration of the measurement point is $1 \mathrm{~s}$.

The range of the shear rate gradient $0.1-350 \mathrm{~s}^{-1}$ corresponds to the range speed of 0.075-270 revolutions per minute.

The device allows the measurement of tangential bias voltage $(t)$ in the range of $0.5-3.010^{4} \mathrm{~Pa}$, gradient of the shear rate $(\gamma)$ from 0.1 to $4000 \mathrm{~s}^{-1}$, and viscosity (h) from 1 to $10^{6} \mathrm{~Pa}$ sec. Using RheoPlus 32 V3.62 software, the hysteresis square ( $\mathrm{A}, \mathrm{Pa} / \mathrm{sec}$ ) was calculated. The points (yield) strength ( $\left.\tau_{0}, P a\right)$ and viscosity at the infinite shear rate $\left(\eta_{\infty}, \mathrm{Pa} \cdot \mathrm{s}\right)$ was calculated using the Casson model: $:^{5,6}$ 
Table 1. Composition of the ointment bases

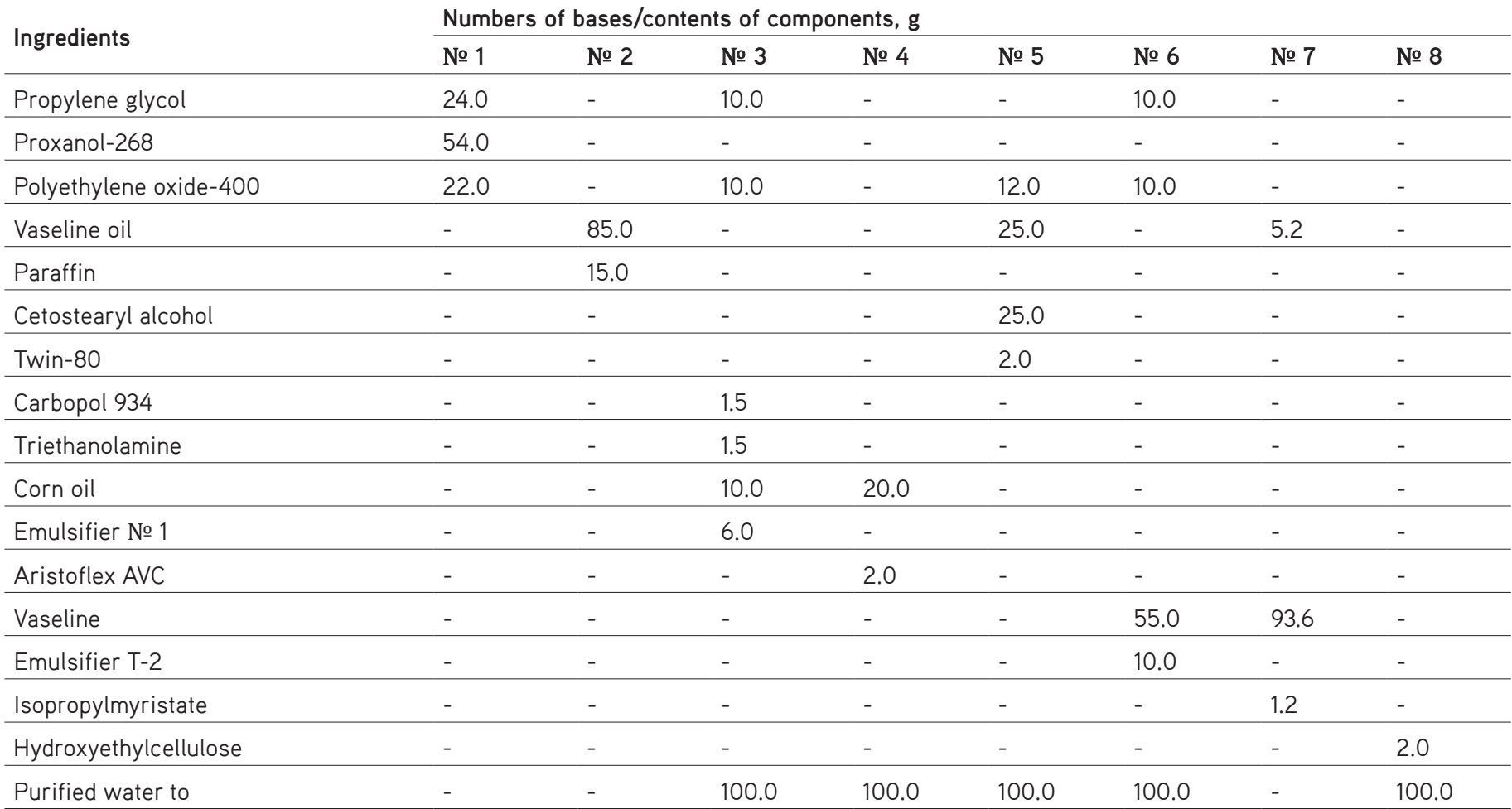

$\tau^{\frac{1}{2}}=\tau_{0}+(\eta \cdot \dot{\gamma})^{\frac{1}{2}}$

where $\tau_{0}$ - yield strength, $\mathrm{Pa}$;

$\eta$ - dynamic viscosity, Pa·s;

$\gamma$ - shear rate, $\mathrm{s}^{-1}$

The Casson model describes an imperfect plastic type of flow, in which there is a disproportionate relationship between shear rate and stress and most closely corresponds to the nature of the flow of the investigated ointment bases.

A coefficient of dynamic flow was determined at the speed rates of 3.4 and $10.2 \mathrm{~s}^{-1}$, which correspond to the velocity of the palm, while soft dosage form distribution over the surface and viscosity of the system was determined at the velocity rates of 27.0 and $155 \mathrm{~s}^{-1}$, which display the velocity of the processing procedure while manufacturing. Based on the results obtained, the values of coefficients of the dynamic flow of the system were calculated by the formulas: ${ }^{5,6}$

$K_{d 1}=\frac{\eta_{3.4}-\eta_{10.2}}{\eta_{3.4}} \cdot 100 \%$

$K_{d 2}=\frac{\eta_{27}-\eta_{155}}{\eta_{27}} \cdot 100 \%$

where $K_{d 1}, K_{d 2}$ - the dynamic flow coefficients;

$\eta$ - apparent viscosity at specified shear rates

For a more complete study of samples, the parameters of their mechanical stability (MS) were calculated. It is known that the optimal value of MS is $1 .^{15}$ The MS value is defined as the ratio of the strength of the structure to failure $\left(\tau_{1}\right)$ to the strength value after fracture $\left(\tau_{2}\right)$ at a shear rate of $3.4 \mathrm{~s}^{-1}$, according to the formula: 5,6

$\mathrm{MS}=\frac{\tau_{1}}{\tau_{2}}$

Statistical data was not used in this research.

\section{RESULTS AND DISCUSSION}

To study the structural and mechanical properties of the experimental samples, complete rheograms of the dependence of the shear stress ( $t$ ) from the shear rate gradient $(\gamma)$ were constructed (Figure 1). A comprehensive assessment of the behavior of the ointment bases during the step-by-step destruction and subsequent restoration (Figure 1) also shows the dependence of viscosity from the shear rate. Sample values of the shear stress and viscosity of the model bases are given in Table 2.

The profile of rheological behavior depends on the composition of the ointment base and varies in a wide range of structural and mechanical parameters (Figure 1). All samples have a pseudoplastic type of flow and the viscosity of the samples decreases disproportionately with increasing shear rate. The samples were exposed to the flow in different ways, which is expressed in the value of the yield strength calculated by the Casson equation: 105.8 Pa, 1.3 Pa, 49.3 Pa, 12.6 Pa, 104.5 Pa, 77.2 Pa, 65.9 Pa, and 0.3 Pa for the samples № 1, № 2, № 3, № 4, № 5, № 6, № 7, and № 8, respectively (Figure 2-8). 


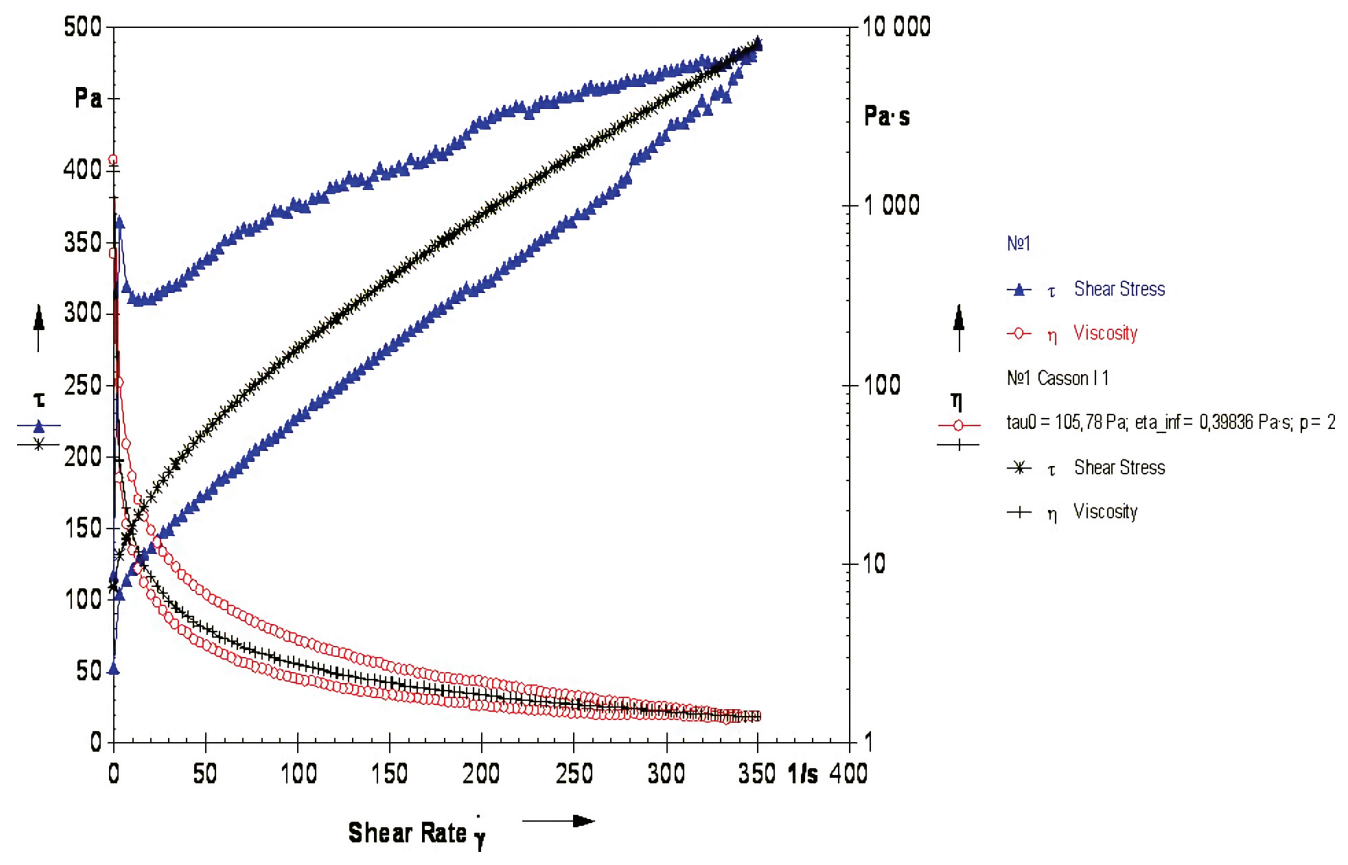

Figure 1. Profile of rheological behavior of sample № 1

\section{Table 2. Parameters of shear stress and structural viscosity of the ointment bases at appropriate shear rate}

Gradient of

shear rate, Shear stress with increasing $\left(\tau_{1}, \mathrm{~Pa}\right) /$ decreasing $\left(\tau_{2}, \mathrm{~Pa}\right)$ shear rate gradient $\left(\gamma, \mathrm{s}^{-1}\right)$

$\left(\gamma, s^{-1}\right)$

\begin{tabular}{|c|c|c|c|c|c|c|c|c|c|c|c|c|c|c|c|c|}
\hline \multirow{3}{*}{$\begin{array}{l}\text { shear rate, } \\
\left(\gamma, s^{-1}\right)\end{array}$} & \multirow{2}{*}{\multicolumn{2}{|c|}{ № 1}} & \multirow{2}{*}{\multicolumn{2}{|c|}{ № 2}} & \multirow{2}{*}{\multicolumn{2}{|c|}{ № 3}} & \multirow{2}{*}{\multicolumn{2}{|c|}{ № 4}} & \multirow{2}{*}{\multicolumn{2}{|c|}{ № 5}} & \multirow{2}{*}{\multicolumn{2}{|c|}{ № 6}} & \multirow{2}{*}{\multicolumn{2}{|c|}{ № 7}} & \multirow{2}{*}{\multicolumn{2}{|c|}{ № 8}} \\
\hline & & & & & & & & & & & & & & & & \\
\hline & $\tau_{1}$ & $\tau_{2}$ & $\tau_{1}$ & $\tau_{2}$ & $\tau_{1}$ & $\tau_{2}$ & $\tau_{1}$ & $\tau_{2}$ & $\tau_{1}$ & $\tau_{2}$ & $\tau_{1}$ & $\tau_{2}$ & $\tau_{1}$ & $\tau_{2}$ & $\tau_{1}$ & $\tau_{2}$ \\
\hline 0.1 & 118 & 52.9 & 43.7 & 0.745 & 8.31 & 21.4 & 2.16 & 29.8 & 128 & 66.1 & 106 & 37.9 & 381 & 16.6 & 0.178 & 2.04 \\
\hline 3.4 & 365 & 104 & 189 & 6.68 & 162 & 121 & 130 & 82.9 & 164 & 106 & 371 & 74.4 & 399 & 79 & 18.3 & 17 \\
\hline 6.8 & 320 & 114 & 219 & 9.53 & 206 & 167 & 144 & 93 & 178 & 130 & 320 & 81.2 & 416 & 87 & 28.3 & 26.6 \\
\hline 10.2 & 312 & 122 & 230 & 11.7 & 225 & 196 & 149 & 99.9 & 194 & 149 & 314 & 86.3 & 467 & 91.7 & 35.1 & 33.6 \\
\hline 13.6 & 310 & 127 & 234 & 13.7 & 244 & 217 & 151 & 105 & 209 & 165 & 317 & 90.3 & 511 & 95.9 & 40.8 & 39.6 \\
\hline 16.9 & 310 & 132 & 233 & 15.5 & 259 & 233 & 157 & 110 & 228 & 178 & 319 & 94.3 & 550 & 99.7 & 45.7 & 44.5 \\
\hline 27.0 & 316 & 147 & 222 & 20.9 & 296 & 260 & 175 & 121 & 275 & 207 & 319 & 104 & 621 & 111 & 57.8 & 57.2 \\
\hline 155.0 & 403 & 282 & 171 & 83.5 & 381 & 386 & 246 & 185 & 607 & 415 & 381 & 202 & 433 & 204 & 122 & 124 \\
\hline 350.0 & 490 & 488 & 199 & 196 & 419 & 418 & 282 & 283 & 742 & 737 & 386 & 380 & 380 & 384 & 167 & 167 \\
\hline
\end{tabular}

Structural viscosity with increasing $\left(\eta_{1}\right.$, Pa.s $) /$ decreasing $\left(\tau_{2}, P a\right)$ shear rate gradient $\left(\gamma, s^{-1}\right)$

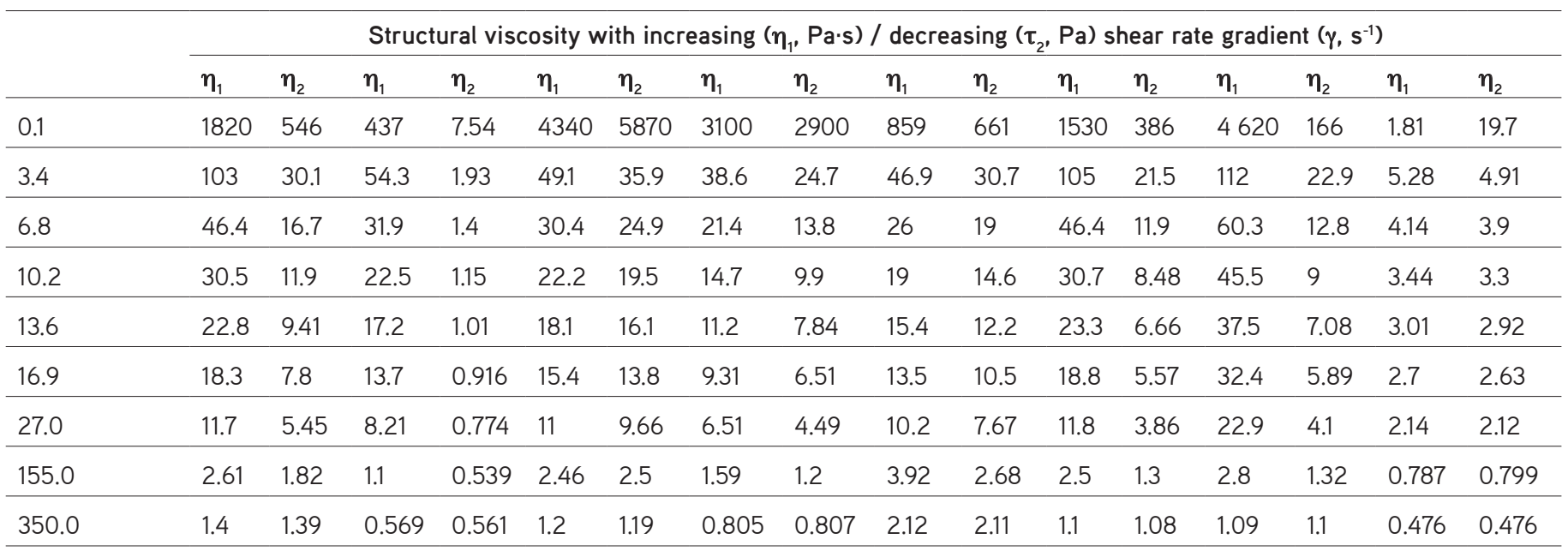


The yield strength is an indicator that shows the force at which the dispersed system begins to flow. In accordance with the value, it is possible to draw a conclusion about how easily the system will be squeezed out, whether the self-flow of the system will be observed, and about the adhesive properties of the drug. Thus, since the sample № 8 has low rheological parameters, the system has a pronounced ability to self-flow due to insufficient concentration of gelling agent. ${ }^{4-6}$ The plan of the experiment envisages a stepwise increase in the rate of destruction of the dispersed system, the flow reflected in the ascending curve, and a subsequent decrease in the rate with the same step. The flow of the system is described by a descending curve.

The ascending curve is located above the descending one and this arrangement of curves is called positive thixotropy, since

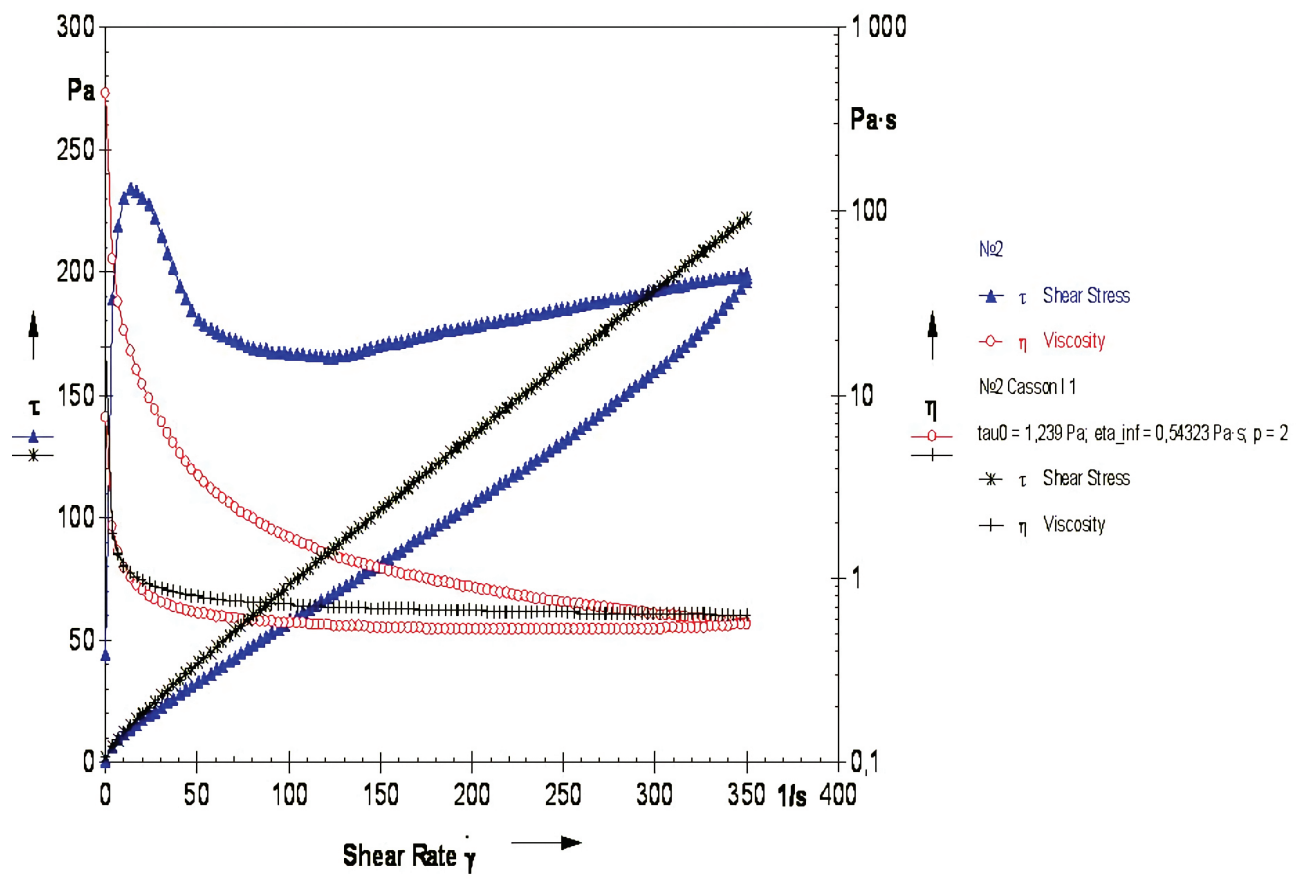

Figure 2. Profile of rheological behavior of sample № 2

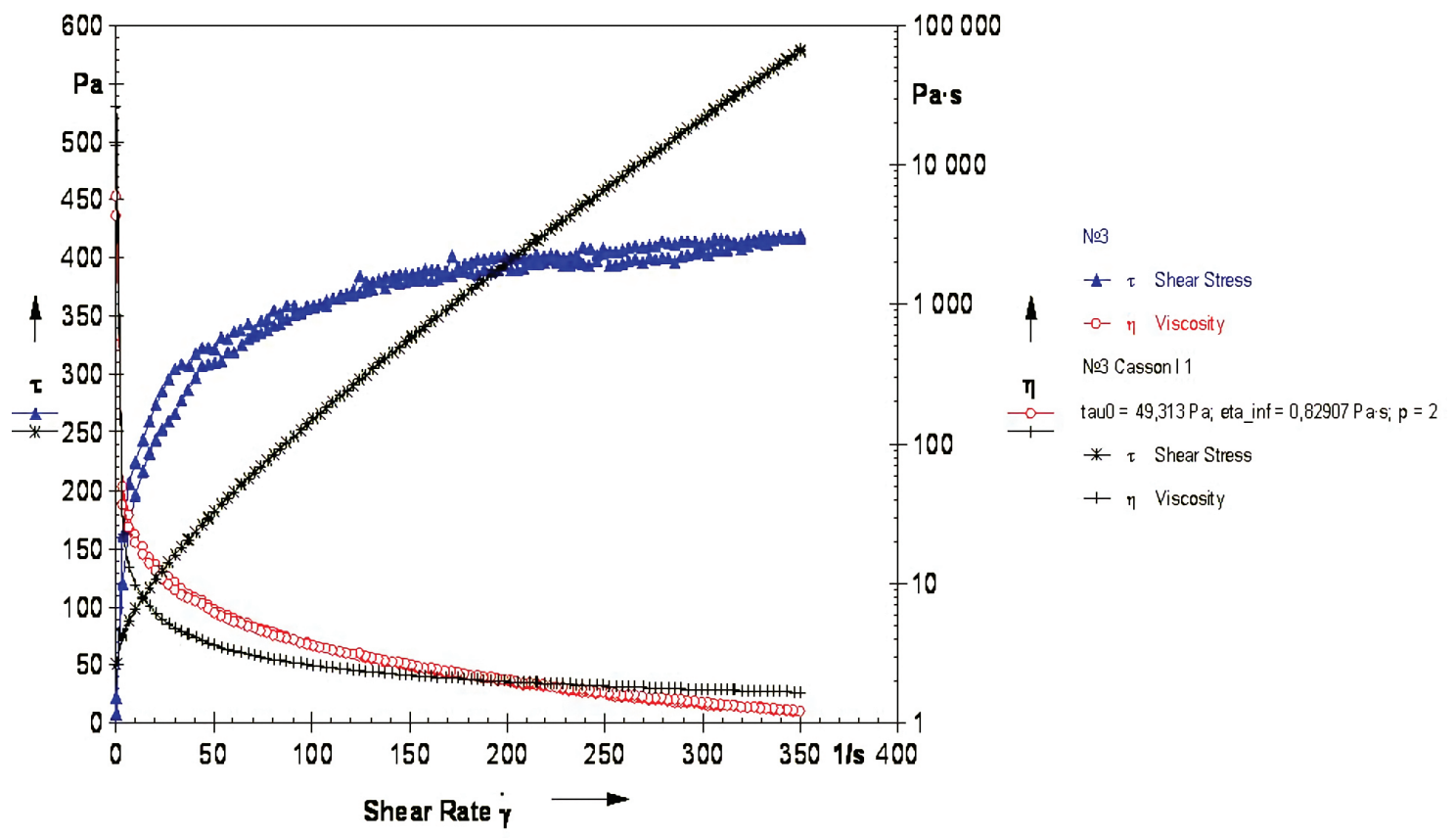

Figure 3. Profile of rheological behavior of sample № 3 
there are such dispersed systems that have antitixotropic or reopective properties. In such systems, the ascending and descending curves are opposite. The investigated ointment bases were restored to varying degrees and the surface area between the ascending and descending curves indicates the thixotropy of the system or ability to recover.11,15 On one hand the smaller the area of the hysteresis loop, the faster the system recovers and, on the other hand, the larger the area, the easier the system is distributed on the surface and on a larger surface area. The first aspect is important in the production process and speaks of the reproducibility of the structured system after the technological process of processing, while

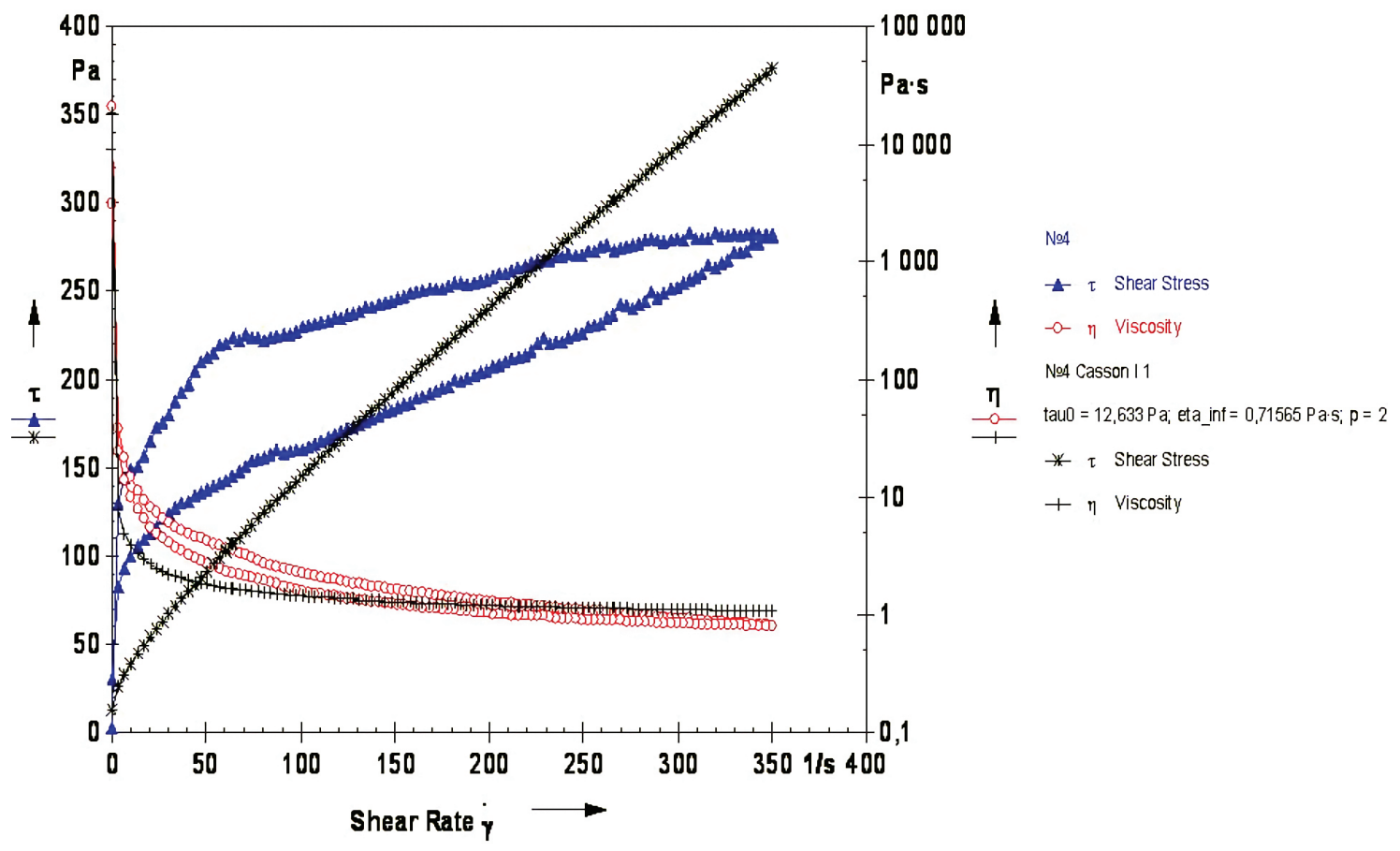

Figure 4. Profile of rheological behavior of sample № 4

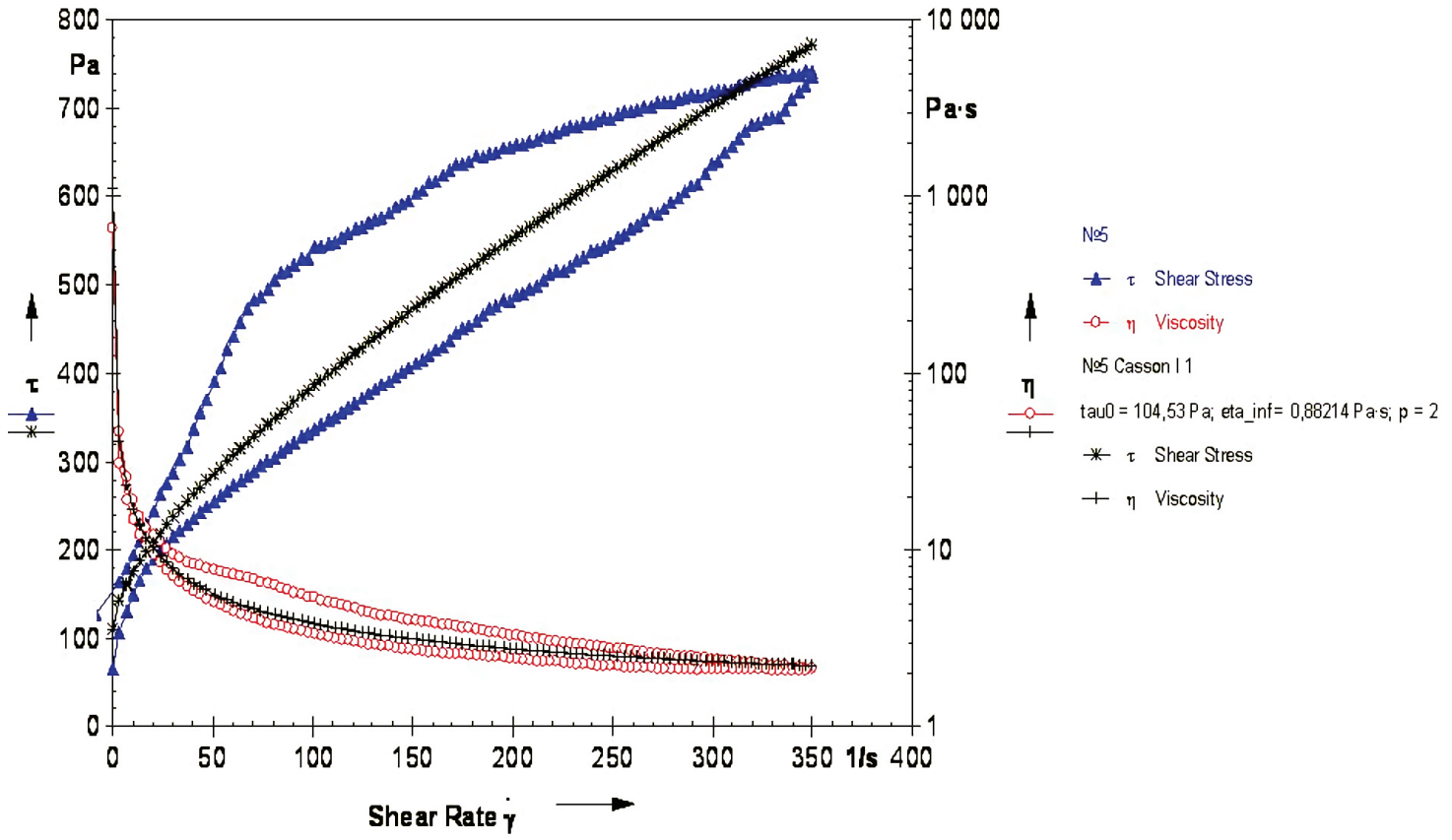

Figure 5. Profile of rheological behavior of sample № 5 
the other is important as a consumer indicator of quality. The hysteresis square for base № 1, № 2 , № 3, № 4, № 5 , № 6, № 7, and № 8 was 38780.5 Pa/s, 30887.8 Pa/s, 40.2 Pa/s, 17242.8 $\mathrm{Pa} / \mathrm{s}$, 49174, $4 \mathrm{~Pa} / \mathrm{s}$, 49521.1 Pa/s, 82587.0 Pa/s, and $319.5 \mathrm{~Pa} / \mathrm{s}$. respectively.

During the period of destruction of structured systems by means of increasing speed of rotation of the internal cylinder, there is a rarefaction of systems, which never comes to an end because some share of communications is restored back, even at high speeds. The viscosity at the infinite shear rate calculated by the Casson model was $0.39 \mathrm{~Pa} / \mathrm{s}, 0.54 \mathrm{~Pa} / \mathrm{s}, 0.83 \mathrm{~Pa} / \mathrm{s}, 0.72 \mathrm{~Pa} / \mathrm{s}$, $0.88 \mathrm{~Pa} / \mathrm{s}, 0,34 \mathrm{~Pa} / \mathrm{s}, 0.44 \mathrm{~Pa} / \mathrm{s}$, and $0.65 \mathrm{~Pa} / \mathrm{s}$ for sample № 1 , № 2, № 3, № 4, № 5, № 6, № 7, and № 8, respectively (Table 3). According to this indicator, the most resistant to the applied

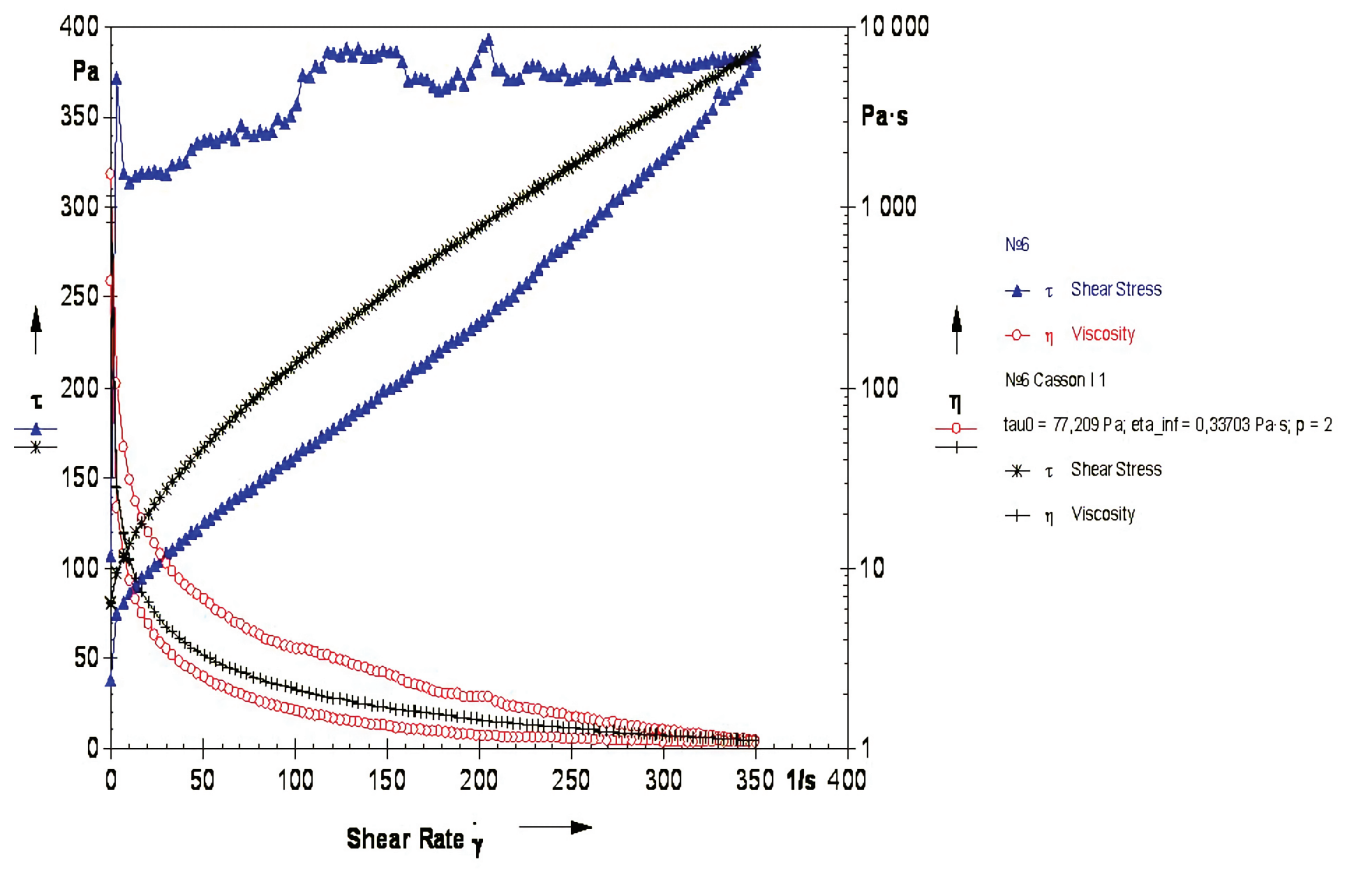

Figure 6. Profile of rheological behavior of sample № 6

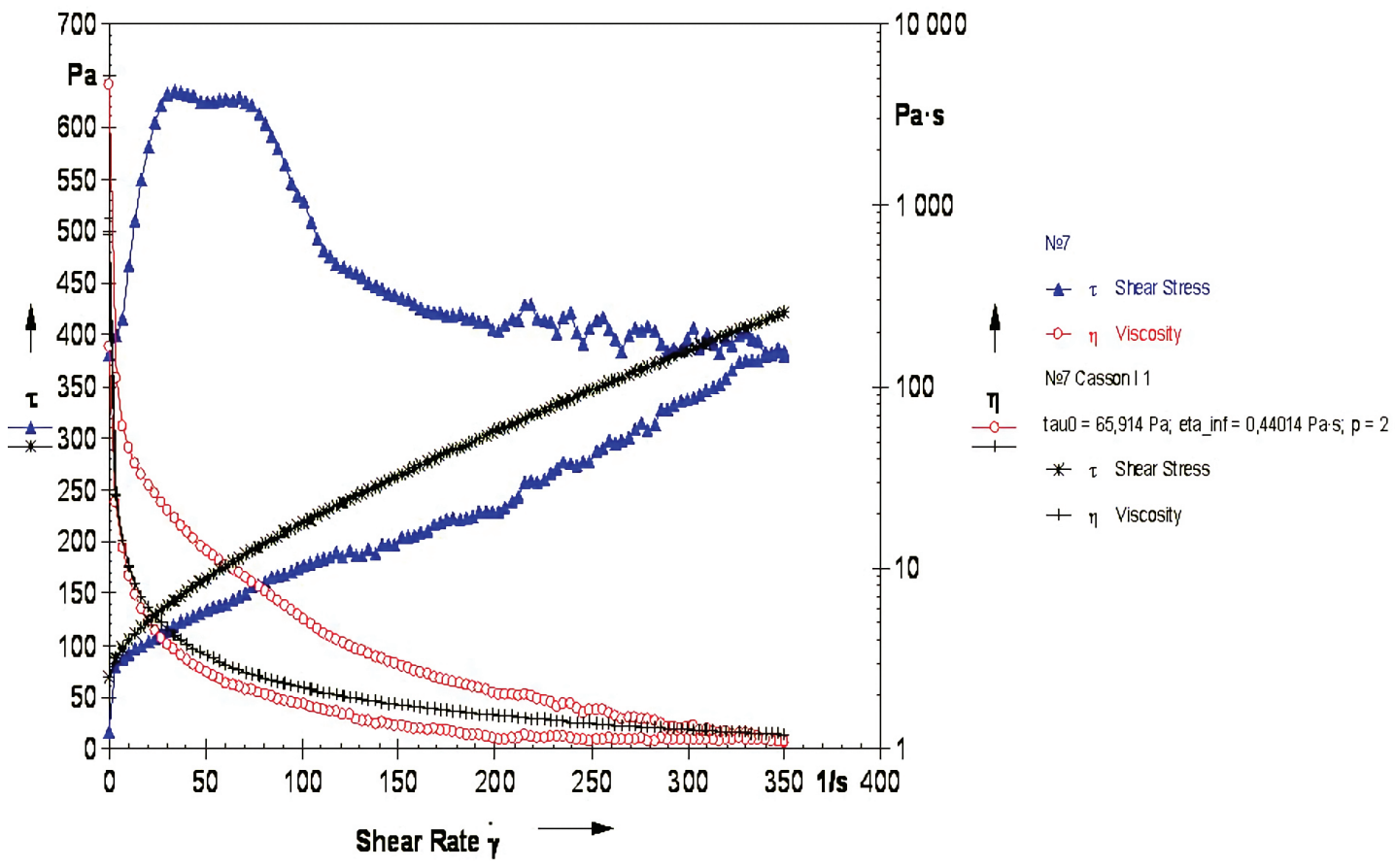

Figure 7. Profile of rheological behavior of sample № 7 
shear force is sample № 8, which had a hydroxyethylcellulose base. Emulsion samples are liquefied to the greatest extent.

The behavior of dispersed systems during destruction is also evaluated by the coefficients of dynamic flow and MS. The coefficient of dynamic flow $\mathrm{Kd}_{1}$ at shear rates of 3.4 and 10.3 $\mathrm{s}^{-1}$ varies in the range from $34.8 \%$ to $95.9 \%$. The coefficient of dynamic flow $\mathrm{Kd}_{2}$ is in the range of even higher values, since systems at higher shear rates are destroyed to a greater extent. The coefficient of MS, calculated as $\gamma 3,4 \mathrm{~s}-1$, serves as a measure of the assessment of the restoration of the structure after the full cycle of destruction-restoration. The closer the calculated value is to 1 , the faster the system recovers, thus indicating a high instantaneous thixotropic properties. From Table 2, we see that the lowest value of the MS index was recorded by sample № 8, which was made using hydroxyethylcellulose. For gel systems, this behavior is typical because as the speed of rotation of the cylinder increases, there is elongation of the molecules of macromolecular matter and, after the cessation of the driving force, the structured orientation of the molecule is restored. In emulsion dispersed systems, which include samples № 3, № 4, № 5, and № 6, the change in viscoplastic properties is due to the sol-gel transition and such systems are restored over time. Homogeneous hydrophobic dispersed systems (samples № 2 and № 7) recover more slowly and the reason for this may be a violation of thermodynamic equilibrium in the system as a result of forced mixing of one layer relative to another or because the viscosity of hydrophobic systems is sensitive to temperature changes.

Samples № 6 and № 7 (Figure 1) have an unstable flow at high shear rates, which can be interpreted as an unstable structure that can stratify over time.

Sample № 2 (based on paraffin and vaseline oil) has a stable homogeneous flow over the entire range of the shear rates, the system is easily propelled, and is characterized by good consumer properties according to the optimum lubrication. According to the set of the rheological parameters, we consider it expedient to use the sample of the ointment base № 2 for further research on the development of the composition of the ointment with antiviral activity.

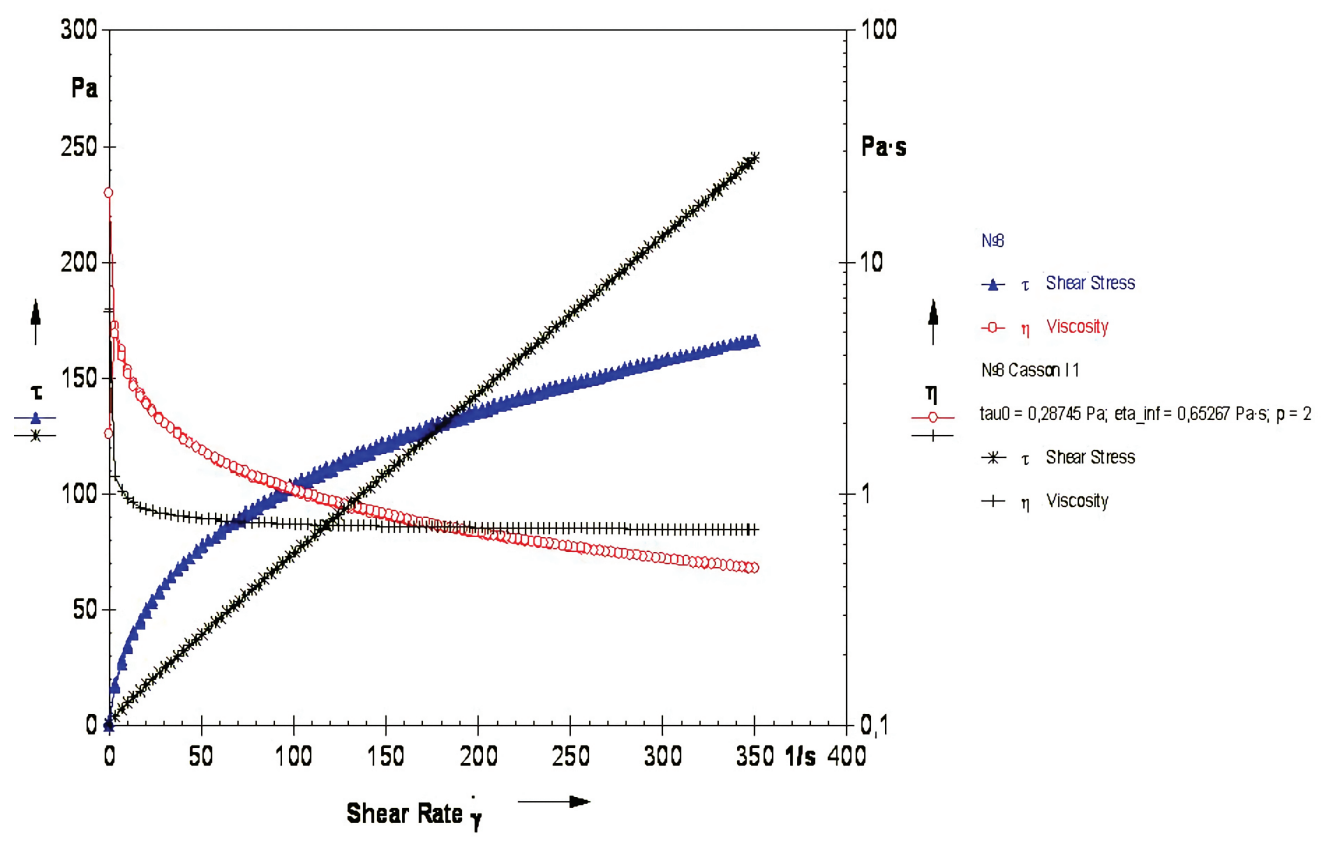

Figure 8. Profile of rheological behavior of sample № 8

Table 3. Structural and mechanical parameters of the ointment bases are calculated

\begin{tabular}{|c|c|c|c|c|c|c|c|c|}
\hline Indicator & № 1 & № 2 & № 3 & № 4 & № 5 & № 6 & № 7 & № 8 \\
\hline Hysteresis square, $\mathrm{Pa} / \mathrm{s}$ & 38780.5 & 30887.8 & 40.2 & 17242.8 & 49174.4 & 49521.1 & 82587.0 & 319.5 \\
\hline Yield strength at Casson $\tau_{0}, \mathrm{~Pa}$ & 105.8 & 1.3 & 49.3 & 12.6 & 104.5 & 77.2 & 65.9 & 0.3 \\
\hline $\begin{array}{l}\text { Structural viscosity at the infinite shear rate at } \\
\text { Casson } \eta \infty, \text { Pa.s }\end{array}$ & 0.39 & 0.54 & 0.83 & 0.72 & 0.88 & 0.34 & 0.44 & 0.65 \\
\hline The coefficient of dynamic flow $\mathrm{Kd} 1, \%$ & 70.4 & 58.6 & 27.1 & 61.9 & 59.5 & 70.8 & 95.9 & 34.8 \\
\hline The coefficient of dynamic flow $\mathrm{Kd} 2, \%$ & 77.7 & 86.6 & 77.6 & 75.6 & 61.6 & 78.8 & 97.7 & 63.2 \\
\hline Mechanical stability at $\gamma 3,4 \mathrm{~s}-1$ & 3.51 & 27.84 & 1.34 & 1.56 & 1.55 & 4.99 & 5.05 & 1.08 \\
\hline
\end{tabular}




\section{CONCLUSION}

The structural and mechanical activity of the ointment bases was studied with help of the rotary viscometer "Rheolab QC" by Anton Paar (Austria) with coaxial cylinders CC27/SSN29766. It was found that all samples have a non-Newtonian pseudoplastic type of flow. It is established that the ointment base № 2, which includes vaseline oil and paraffin, exhibits a homogeneous rheological flow.

Further research will focus on the development of composition of ointments with the antiviral effect.

Conflict of interest: No conflict of interest was declared by the authors. The authors are solely responsible for the content and writing of this paper.

\section{REFERENCES}

1. Shegokar R, Shaal LAL, Mishra PR. SiRNA Delivery. Challenges and role of carrier systems. Die Pharmazie. 2011;66:313-318.

2. Mezger TG. The Rheology Handbook. Hanover: Vincentz Network; 2014:432.

3. Goodwin JW, Hughes RW. Rheology for Chemists: An Introduction. Cambridge: Cambridge University Press; 2000:299.

4. Rukhmakova OA, Yarnykh TG, Kovalenko SN. The development of industrial technology of the ointment codenamed "Alergolik". Res J Pharm Tech. 2017;10:1994-1997.

5. Kukhtenko H, Gladukh I, Kukhtenko O, Soldatov D. Influence of excipients on the structural and mechanical properties of semisolid dosage forms. Asian J Pharm. 2017;11:575-578.

6. Gladukh I, Grubnik I, Kukhtenko H. Structural-mechanical studies of phytogel "Zhivitan”. J Pharm Sci Res. 2017;9:1672-1676.

7. Ivko T, Aslanian M, Bobrytska L, Popova N, Nazarova O, Bereznyakova $\mathrm{N}$, Germanyuk T. Development of the composition and manufacturing technology of the new combined drug Lavaflam. Turk J Pharm Sci. 2018;3:263-270.

8. Nwoko VE. Semi solid dosage forms manufacturing: tools, critical process parameters, strategies, optimization and validation. Sch Acad J Pharm. 2014;3:153-161.

9. Fares R, Bobrytska L, Germanyuk T. Diaplant: manufacturing technology and rationalization of costs of acute intestinal infection pharmacotherapy. Int J Green Pharm. 2017;11:584-589.

10. Caggioni M, Spicer PT, Blair DL, Lingerg SE. Rheology and microrheology of a microstructured fluid the gellan. J Rheology. 2007;51:851-865.

11. Kolpakova OA, Kucherenko NV, Kukhtenko HP. Research of rheological properties of ointment with water-saluble protein-polysaccharide complex of oyster mushroom. J Pharm Sci Res. 2019;11:1880-1883.

12. Neel JM, Neel DP, Jay P, Divyesh HS, Pragna KS. Development and evaluation of antiarthritic herbal ointment. Res J Pharm Biol Chem Sci. 2013;4:221-228.

13. Hrytsenko VI, Kienko LS, Bobrytska LO. The study of the antimicrobial activity of a soft dosage form with the antiviral effect. Clin Pharm. 2019:2:25-28

14. Rebecca CB, David IB. Treatment of herpes simplex virus infections. Antiviral Res. 2004;61:73-81.
15. Grubnik I, Gladukh I. Study of the rheological properties of natural gums. Br J Educ Stud. 2015;2:689-669.

16. Aslanyan MA, Bobrytska LO, Nazarova ES, Mirnaya TA, Zborovskaya TV. Development and validation of method for the quantitative determination of lavender oil in lavaflam preparation by gas chromatography. Pharm Chem J. 2016;50:47-51.

17. Aslanyan M, Bobrytska L, Hrytsenko V, Shpychak O, Popova N Germanyuk T, Kryvoviaz O, Ivko T. Technological aspects of development of a new drug in tablets called "Lavaflam" and its pharmacoeconomic evaluation. Res J Pharm Biol Chem Sci. 2017;4:808-814.

18. Aslanian M, Bobrytska L, Bereznyakova N, Shpychak H, Hrytsenko V Germanyuk T, Ivko T. Biochemical research of hepatoprotective activity of tablets Lavaflam in rats with subchronic hepatitis. Curr Issues Pharm Medical Sci. 2020;32:10-13.

19. Bobrytska LO, Kovalev VV, Spyrydonov SV, Ivko TI, Germanyuk TA, Gordzievska NA. Diaplant-NEO: Complex therapy of acute intestinal infections. Trends Pharm Res Dev. 2020;2:145-153.

20. Nesterova IV, Khalturina EO. Mono- and mixed-herpesvirus infections: association with clinical syndromes of im-munodeficiency. RUDN J Med. 2018;22:226-234

21. Bobrytska LO, Fares R, Goncharov MI, Nazarova OS, Popova NV, Litvinenko VI. Drug of antimicrobial, anti-inflammatory and antispasmodic action: patent 103886 Ukraine. № u2015 04344; declared 05.05.2015; published 12.01.2016, Bulletin no: 1 .

22. Gritsenko VI, Kienko LS, Bobritskaya LO, Shpychak OS, Germanyuk TA, Nazarova OS. Pharmaceutical composition of soft dosage form with antiviral action: patent 134507 of Ukraine on utility model: international patent classification A61P 31/04. № in 201811079; declared 11/09/18; publ. 27.05.19, Bull. no: 10 .

23. Kienko L, Hrytsenko V, lakovlieva L, Bobrytska L. Marketing analysis of the assortment of drugs for the treatment of herpes viral diseases at the pharmaceutical market of Ukraine. Eureka: Health Sciences. 2020;3:7076.

24. Hrytsenko VI, Kienko LS, Bobrytska LA, Rybalko SL, Starosila DB. Study of anti-herpetic activity of a soft dosage form with acyclovir and miramistin. J Glob Pharma Technol. 2020;12:397-404.

25. Aslanian MA, Bobrytska IA, Bereznyakova NL, Shpychak OS, Germanyuk T, Ivko TI. Histological research of hepatoprotective activity of tablets Lavaflam in rats with subchronic hepatitis. Zaporozhye Medical Journal. 2018;182-187.

26. Hrytsenko V, Gubar S, Ruban O, Kutsenko S, Bobrytska L, Germanyuk T. Development of the method of identification and quantitation of active ingredients in suppositories "phytoprost". Asian J Pharm. 2018;49-53.

27. Rowe RC, Sheskey PJ, Owen SC. Handbook of Pharmaceutical Excipiets. London: Pharmaceutical Press; 2006.

28. Dhawan S, Varma M, Sinha VR. High molecular weight poly(ethylene oxide)-based drug delivery systems. Part 1: hydrogeles and hydrophilic matrix systems. Pharm Technol. 2005;29:72-80.

29. WHO. State Pharmacopoeia of Ukraine. V. 2. Ch. 2. Kharkiv 2014. Available from: https://www.who.int/medicines/areas/quality_safety/ quality_assurance/resources/Ukranian_Pharmacopoeia.pdf?ua=1

30. Schaefer MJ, Singh J. Effect of isopropyl myristic acid ester on the physical characteristics and in vitro release of etoposide from PLGA microspheres. AAPS PharmSciTech. 2000;1:E32. 